\title{
Permasalahan Restorasi Dan Konservasi Penerapannya pada Candi Morangan, Yogyakarta
}

\section{Muhammad Chawari}

Keywords: restoration, conservation, temple, hindu-buddha, protection, reconstruction

\section{How to Cite:}

Chawari, M. (2005). Permasalahan Restorasi Dan Konservasi Penerapannya pada Candi Morangan, Yogyakarta. Berkala Arkeologi, 25(1), 23-30. https://doi.org/10.30883/jba.v25i1.907

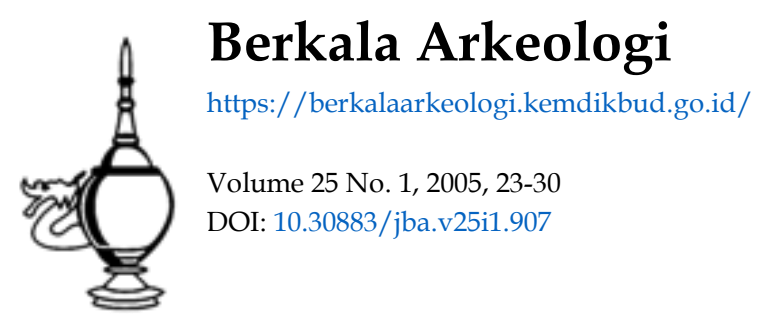

\section{c) (7) (2)}

This work is licensed under a Creative Commons Attribution-NonCommercial-ShareAlike 4.0 International License. 


\title{
PERMASALAHAN RESTORASI DAN KONSERVASI Penerapannya pada Candi Morangan, Yogyakarta
}

\author{
Oleh : Muhammad Chawari
}

\section{Beberapa Konsep tentang Restorasi dan Konservasi}

\section{A. Restorasi}

1. Usaha memperbaiki sesuatu (bangunan) yang sudah rusak agar pulih kembali sesuai dengan aslinya dengan menggunakan dan menempatkan kembali bahanbahan bangunan aslinya sesuai dengan susunan dan tata letaknya semula (Soekmono, 1996: 43). Tidak boleh ada penggantian dan penambahan (Soekmono, 1993/1994: 280) sesuatu yang baru dengan tujuan melengkapi kekurangan, kecuali bilamana tanpa penambahan itu pekerjaan tidak mungkin dilaksanakan, tetapi dibatasi sampai pada yang bersifat teknis semata (Soekmono, 1993: 2).

2. Suatu kegiatan untuk melestarikan bangunan seperti keadaan semula dan menghindarkan pembongkaran apalagi relokasi gedung (bangunan) tersebut (Atmadi, 1981: 44).

3. Pemakaian bahan-bahan baru (batu dan atau bata) merupakan kegiatan gabungan antara restorasi dan rekonstruksi (Subroto, 2003: 2 Oktober).

\section{B. Konservasi}

1. Merupakan kegiatan yang dilakukan paling akhir dari serangkaian kegiatan terhadap tingkat perubahan dalam suatu pemugaran (Atmadi, 1981: 45). Pendapat tersebut mengutip pemikiran Dobby (1978) dalam bukunya Conservation and Planning.

2. Merupakan serangkaian tindakan untuk mengawetkan dan melestarikan benda dari proses pelapukan, khususnya yang bahannya terbuat dari kayu (Soenarto dkk, 1987: 6; 29-59)

3. Merupakan suatu kegiatan yang dibedakan menjadi 2 berdasarkan skalanya (Anom, 2003: 14 Oktober), yaitu:

a. Skala sempit, berkaitan dengan kerja pemeliharaan dan perkuatan teknis, baik secara manual maupun kimia.

b. Skala luas, berkaitan dengan pelestarian yang di dalamnya mencakup perlindungan, pemeliharaan, pemugaran, dan pemanfaatan.

4. Berhubungan dengan pemanfaatan yaitu mengelola dan memelihara agar dapat dimanfaatkan lebih lama dengan tetap mempertahankan makna kulturalnya (Soebroto, 2003: 18 September). Selanjutnya, Subroto mengatakan bahwa kerja konservasi meliputi: 

a. Maintenance yaitu pemeliharaan yang berkesinambungan.
b. Preservation yaitu pengawetan objek tanpa adanya perubahan.
c. Restoration yaitu mengembalikan objek pada keadaan sebenarnya tanpa memakai bahan baru.
d. Reconstruction yaitu mengembalikan objek pada keadaan mendekati aslinya.
e. Adaptation yaitu memodifikasi objek sesuai dengan penggunaannya.

\section{Lokasi dan Keadaan Lingkungan Candi Morangan}

Candi Morangan terletak di wilayah Dusun Morangan, Desa Sindumartani, Kecamatan Ngemplak, Kabupaten Sleman, Propinsi Daerah Istimewa Yogyakarta. Secara astronomis candi ini terletak antara $110^{\circ} 28^{\prime} 4,71^{\prime \prime}$ BT dan $7^{\circ} 41^{\prime} 5,57^{\prime \prime}$ LS. Candi tersebut berada di tengah-tengah permukiman penduduk. Untuk mencapai lokasi candi tidak susah, hanya saja karena terletak di tengahtengah permukiman dan jalan yang ada merupakan jalan kampung yang belum dan atau tidak diaspal. Hal ini, mengakibatkan akses ke lokasi candi agak kurang lancar.

Lokasi Candi Morangan mempunyai batas-batas:

- Sebelah utara berbatasan dengan permukiman penduduk.

- Sebelah timur berbatasan dengan jalan desa.

- Sebelah selatan berbatasan dengan jalan desa yang sekaligus merupakan batas antara Desa Morangan dengan Desa Kalimanggis.

- Sebelah barat berbatasan dengan permukiman penduduk.

Selain itu untuk mencapai ke lokasi Candi Morangan dapat ditempuh melalui jalan raya Yogyakarta - Solo, sesampainya di pertigaan jalan yang menuju ke Cangkringan belok ke utara, setelah sampainya di Dinas Perikanan Cangkringan belok ke timur kurang lebih $2 \mathrm{~km}$ atau tepatnya di sebelah barat Sungai Gendol belok ke selatan masuk ke jalan desa sejauh kurang lebih $1 \mathrm{~km}$, di sebelah barat jalan desa tersebut terletak Candi Morangan. Candi Morangan terletak di antara dua sungai, yaitu Sungai Gendol di sebelah timur berjarak kurang lebih 100 meter dan Sungai Opak di sebelah barat berjarak kurang lebih 600 meter.

Keadaan tanah di sekitar lokasi candi merupakan batu pasir krikilan. Tanah tersebut sebagian merupakan akibat aktivitas Gunung Merapi, dibawa melewati Sungai Gendol, yang terletak di sebelah timur Candi Morangan.

\section{Deskripsi Candi Morangan}

Candi Morangan telah ditemukan sejak jaman pemerintahan Belanda. Hal ini dapat dilihat di ROD tahun 1915 (Bosch, 1915: 12). Setelah Belanda meninggalkan 
Indonesia, penanganan Candi Morangan terhenti, sehingga candi tersebut kembali tertutup tanah. Pada sekitar tahun 1982 BP3 D.I. Yogyakarta kembali mengadakan ekskavasi lanjutan, tetapi hingga saat ini masih tertunda karena permasalahan beaya. Ketika candi ini ditemukan kembali sebagian sisa-sisa batu candi berada di permukaan tanah. Ketinggian pada saat ditemukan kembali adalah sekitar 1,5 meter dari permukaan tanah. Ekskavasi yang telah dilakukan oleh BP3 berhasil menampakkan 2 buah bangunan candi, yaitu satu buah candi induk dan satu buah candi perwara. Bangunan candi induk menghadap ke barat, sedangkan candi perwara terletak di depan candi induk agak geser ke utara dan menghadap ke timur.

\section{A. Candi Induk}

Hingga saat ini karena masih adanya kendala teknis, bangunan candi induk belum seluruhnya dapat ditampakkan. Bagian fondasi dan kaki candi berada pada kedalaman sekitar 4 meter dari permukaan tanah sekarang. Berdasarkan laporan awal diketahui bahwa tinggi bagian batur dan kaki candi mencapai 3,20 meter. Ukuran denah candi 7,90 X 7,90 meter dan bagian anak tangga terdapat di sisi barat yang lebarnya 1,70 meter. Lebar lantai selasar berkisar antara 0,50 s.d.

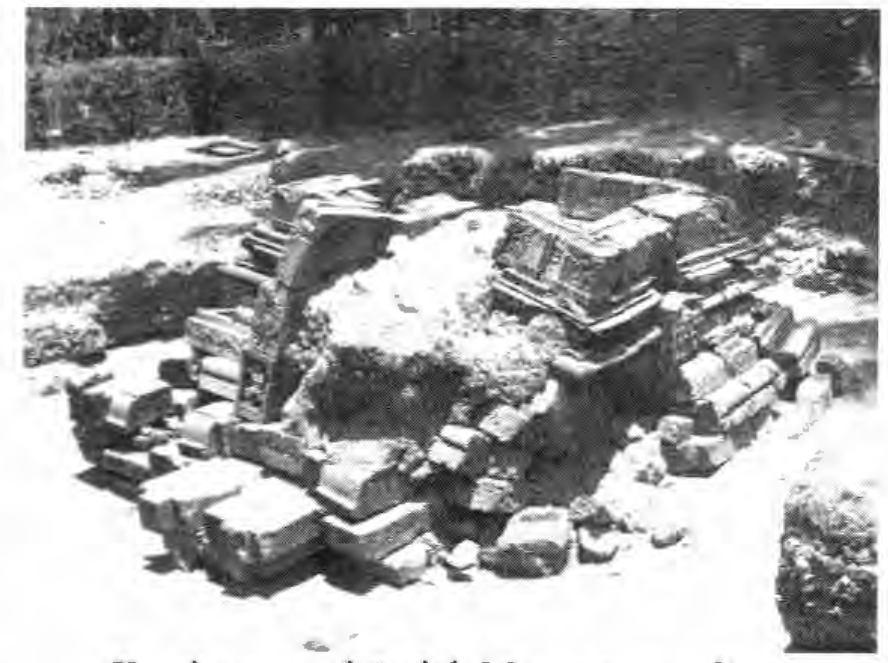

Keadaan candi induk Morangan, aslinya berada di bawah permukaan tanah yang sekarang 0,70 meter dengan ketinggian seluruhnya yang belum diketahui dengan pasti. Sampai sekarang candi tersebut belum dipugar, sehingga arsitektur candi secara utuh belum dapat diketahui. Bagian atap candi sementara ini belum dapat direkonstruksi secara utuh karena banyak batu yang belum ditemukan. $\mathrm{Di}$ atas kaki candi terdapat tubuh candi bagian pertama yang berukuran $3,76 \mathrm{X}$ 3,76 meter dan tinggi tanpa pelipit batas adalah 1,55 meter. Di atas tubuh candi pertama terdapat tubuh candi II yang berukuran 3,76 X 3,76 meter dengan ketinggian 1,90 meter (termasuk pelipit batas antara bagian tubuh dengan bagian atap (Nugroho, 2000: $64-65$ ). 


\section{B. Candi Perwara}

Di sebelah barat laut candi induk terdapat candi perwara yang berukuran lebih kecil, yaitu sekitar 4,08 X 4,08 meter dan tinggi bagian kaki 1,56 meter. Yang tersisa pada candi perwara adalah bagian kaki dan sebagian kecil tubuh candi. Dari bagian tubuh candi yang tersisa diketahui bahwa bagian ini berukuran 2,5 X 2,5 meter. Bagian tubuh dan atap candi belum dapat direkonstruksi karena batu-batu yang ditemukan tidak lengkap. Sisa-sisa bangunan candi perwara yang menghadap ke timur miring ke arah utara, sebab pada bagian dasar dan kaki candi sisi utara telah terlepas dan tidak menyatu lagi. Berdasarkan pengamatan pada bagian atap candi induk yang telah mengalami percobaan penyusunan kembali dapat diperkirakan bahwa

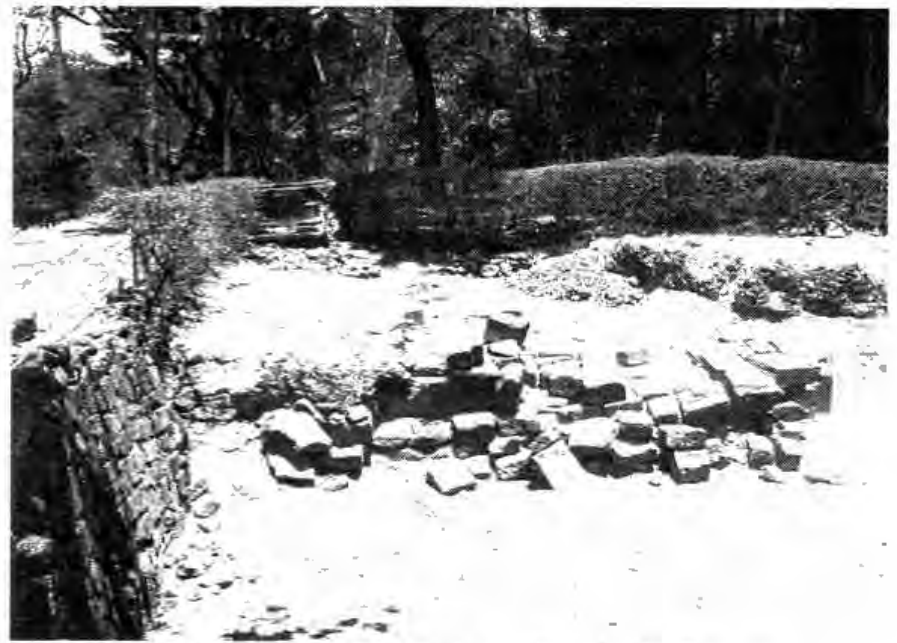

Candi perwara yang terletak di depan (timur) candi induk bentuk atap candi bertingkat yang dilengkapi dengan menara-menara atau kemuncak yang berlanjut dari bagaian kepala kala pada tubuh II (Nugroho, 2000: 65-66).

Walaupun candi ini telah diberi pagar keliling dan ditempatkan beberapa petugas dari BP3 Prop. D.I. Yogyakarta. Untuk masuk ke kompleks candi tidak ditarik retribusi, seperti candi-candi lain di Yogyakarta. Hal ini dimungkinkan karena candi tersebut belum dipugar sebagaimana mestinya. Keadaannya sekarang, hampir sebagian batu-batu candi telah diangkat untuk direkonstruksi ulang diletakkan di bagian lain dari kompleks ini. Berdasarkan seni hias dan arsitekturnya, Candi Morangan diperkirakan dibangun sekitar abad IX (Prajudi, 1999: 137).

\section{Perlukah Pemugaran Candi Morangan Dilakukan?}

Sebelum menjawab pertanyaan di atas, perlu kiranya diihat kembali istilah konservasi. Hal itu penting karena ada beberapa pendapat yang berlainan tentang istilah konservasi. Menurut Parmono Atmadi dalam sebuah tulisannya yang berjudul Beberapa Masalah dan Aspek Utama dalam Kegiatan Pemugaran Bangunan Sejarah dan Purbakala, mengatakan bahwa konservasi merupakan salah satu kegiatan dalam pemugaran. Kemudian Th. Aq. Soenarto dalam Laporan Konservasi-Arkeologi Masjid Besar Kauman Yogyakarta pada tahun 1987 mengatakan bahwa konservasi adalah usaha untuk mengawetkan dan melestarikan benda dari proses pelapukan, khususnya yang bahannya terbuat dari 
melestarikan benda dari proses pelapukan, khususnya yang bahannya terbuat dari kayu. Sedangkan I.G.N. Anom dalam suatu pertemuan mengatakan bahwa konservasi dibedakan menjadi 2 berdasarkan skalanya, yaitu skala sempit yang berkaitan dengan kerja pemeliharaan dan perkuatan teknis, dan skala luas yang berkaitan dengan pelestarian, perlindungan, pemeliharaan, pemugaran, dan pemanfaatan. Sementara itu, $\mathrm{Ph}$. Soebroto dalam suatu pertemuan mengatakan, bahwa konservasi berkaitan erat dengan pemanfaatan mengelola dan pemeliharaan sumberdaya arkeologi agar dapat dimanfaatkan lebih lama dengan tetap mempertahankan makna kulturalnya. Dalam prakteknya kegiatan tersebut meliputi maintenance (pemeliharaan yang berkesinambungan), preservation (pengawetan objek tanpa adanya perubahan), restoration (mengembalikan objek pada keadaan sebenarnya tanpa memakai bahan baru), reconstruction (mengembalikan objek pada keadaan mendekati aslinya), dan adaptation (memodifikasi objek sesuai dengan penggunaannya).

Berdasarkan beberapa pendapat di atas, penulis dapat membagi konservasi menjadi 2 berdasarkan kronologinya, yaitu:

a. Pendapat lama, mengatakan bahwa konservasi merupakan bagian dari kegiatan pemugaran, artinya bahwa kerusakan yang berkaitan dengan konstruksi dapat dilakukan dengan pemugaran, yang diikuti dengan tindakan konservasi. Konservasi di sini diartikan sebagai pengawetan atau penguatan, misalnya konservasi kayu pada Masjid Besar Kauman Yogyakarta (Soenarto, 1987: 5 dan 29-59).

b. Pendapat baru, yaitu bahwa konservasi merupakan kegiatan payung yang di dalamnya terdiri atas beberapa kegiatan, salah satunya adalah pemugaran.

Selanjutnya untuk menjawab pertanyaan Perlukah Pemugaran Candi Morangan dilakukan, tentunya akan sangat tergantung kondisi batu-batu yang ditemukan cukup untuk memugar kembali. Pemugaran yang dimaksud terbatas pada menegakkan atau memperbaiki kembali Candi Morangan yang telah runtuh. Menurut pendapat Soekmono pemugaran (restoration) sebuah candi adalah usaha memperbaiki sesuatu (bangunan) yang sudah rusak agar pulih kembali sesuai dengan aslinya dengan menggunakan dan menempatkan kembali bahan-bahan bangunan aslinya sesuai dengan susunan dan tata letaknya semula. Tidak boleh menambah atau membuat sesuatu yang baru dengan tujuan melengkapi kekurangan. Apabila pendapat tersebut diterapkan pada Candi Morangan akan mengalami banyak kesulitan. Pasalnya Candi Morangan sekarang ini telah banyak sekali kehilangan batu-batu aslinya. Selanjutnya, Soekmono mengatakan bahwa tanpa penambahan (baca: penggantian) batu-batu yang telah hilang pekerjaan pemugaran tidak mungkin dilakukan, tetapi dibatasi hanya sampai pada hal yang bersifat teknis semata. Dengan demikian sebetulnya pemugaran Candi Morangan dapat dilaksanakan, tetapi dengan syarat yang amat berat. Berdasarkan 
pendapat Soekmono tersebut jika dikaitkan dengan pemugaran Candi Morangan dapat dijelaskan sbb:

a. Pemugaran Candi Morangan dapat dilakukan dengan mengganti batu-batu yang hilang, tetapi batu-batu tersebut bersifat struktural artinya bahwa tanpa mengganti batu-batu yang hilang pemugaran tidak dapat dilaksanakan.

b. Apabila batu-batu yang hilang merupakan batu-batu yang berelief, maka batu-batu tersebut tidak boleh diganti dengan batu baru, kecuali bila tanpa batu tersebut pekerjaan pemugaran tidak dapat dilaksanakan, maka batu pengganti harus polos dan tidak diukir.

c. Batu-batu baru sebagai pengganti batu yang telah hilang dapat diberi tanda (pin) yang berupa logam (timah) untuk membedakan antara batu asli dengan batu baru. Hal ini seperti yang telah dilakukan di Candi Borobudur.

Meskipun demikian, sebelum dilaksanakan pemugaran harus dilakukan rekonstruksi terlebih dahulu untuk mengetahui bentuknya secara lebih jelas. Seperti telah disebutkan di atas, bahwa ekskavasi yang telah dilakukan berhasil menampakkan 2 buah candi, yaitu candi induk dan perwara yang tidak utuh lagi. Rekonstruksi percobaan atau sementara sifatnya telah dilakukan di bagian barat candi. Secara teknis bentuk rekonstruksi dapat dibagi menjadi 3 berdasarkan pentahapannya, yaitu:

a. Rekonstruksi Sementara. Rekonstruksi ini bertujuan untuk melihat sejauhmana batu-batu candi yang masih tersisa dan masih atau dapat ditemukan. Berkaitan dengan rekonstruksi sementara Candi Morangan yaitu terhadap candi induk dan 1 buah candi perwara, baru dapat dilakukan hingga bagian tubuh candi, mengingat batu yang ditemukan belum cukup.

b. Rekonstruksi di Atas Kertas. Rekonstruksi ini merupakan bentuk rekonstruksi dua dimensi seperti yang tertuang dalam studi kelayakan (Soekmono, 1993: 4). Rekonstruksi dua dimensi ini merupakan bagian paling penting dalam pemugaran, sebab hasil gambar yang diperoleh berdasarkan hasil "penjodohan" antara batu satu dengan lainnya yang menjadi bagian dari keseluruhan bangunan. Selain itu, gambar rekonstruksi dua dimensi ini merupakan pemandu dalam anastylosis. Sesungguhnya rekonstruksi ini merupakan hal yang dapat dipakai untuk menentukan dapat atau tidaknya rekonstruksi tiga dimensi (rekonstruksi sesungguhnya) dilakukan (Soekmono, 1993/1994: 282).

c. Rekonstruksi Sesungguhnya. Rekonstruksi ini merupakan bentuk rekonstruksi tiga dimensi dan merupakan pemugaran yang sesungguhnya. 
Dengan demikian sebelum Candi Morangan dipugar, seharusnya dilakukan rekonstruksi di atas kertas terlebih dahulu, agar segala sesuatunya sesuai dengan aturan dan tidak menyimpang.

\section{Penutup}

Berdasarkan uraian di atas, ada beberapa hal yang dapat dikemukakan, yaitu:

1. Dalam upaya pelestarian (termasuk pemeliharaan) dan pemanfaatan (termasuk pengelolaan) yang merupakan kegiatan pokok (payung) adalah berupa konservasi yang di dalamnya termasuk pemugaran. Jadi pemugaran (restoration) merupakan salah satu bentuk kegiatan dalam konservasi, di samping pemeliharaan (maintenance), pengawetan (preservation), rekonstruksi (reconstruction), dan modifikasi (adaptation).

2. Untuk memugar Candi Morangan terlebih dahulu yang harus dilakukan adalah rekonstruksi di atas kertas. Rekonstruksi ini untuk melihat sejauhmana pemugaran Candi Morangan dapat dilakukan.

\section{DAFTAR PUSTAKA}

Anom, I.G.N. 2003. Penjelasan yang disampaikan di Yogyakarta pada tanggal 14 Oktober 2003.

Atmadi, Parmono. 1981. Beberapa Masalah Dan Aspek Utama Dalam Kegiatan Pemugaran Bangunan Sejarah Dan Purbakala dalam Majalah Arkeologi Tahun IV, No. 1 - 2. Lembaga Arkeologi

Fakultas Sastra Universitas Indonesia, Jakarta.

Bosch, F.D.K. 1915. Inventaris den Hindoe - Oudheiden dalam ROD Twede Deel.

Nugroho, Suwarso Alip. 2000. Pengaruh Letusan Gunung Merapi Terhadap Candi Sambisari, Candi Kedulan, dan Candi Morangan. Skripsi. Jurusan Arkeologi, Fakultas Sastra, Universitas Gadjah Mada.

Prajudi, Rahadhian, H. 1999. Kajian Tipo - Morfologi Arsitektur Candi Di Jawa. Thesis S2. Program Studi Arsitektur pada Institut Teknologi Bandung. 
Soekmono, R. 1993. Ratu Boko Quo Vadis? Dalam Pertemuan Teknis Evaluasi Program Pemugaran Boko. Bagian Proyek Pelestarian/Pemanfaatan Peninggalan Sejaran dan Purbakala Propinsi Daerah Istimewa Yogyakarta.

-----. 1993/1994. Pemugaran dan Arkeologi. Dalam Pertemuan IImiah Arkeologi VI (PIA VI), Malang. Ikatan Ahli Arkeologi Indonesia.

-.-. 1996. Langkah Pemerintah Tahun 1948 dalam Bidang Kepurbakalaan: Landasan untuk Pengembangan Arkeologi Indonesia. Dalam Jurnal Arkeologi Indonesia Nomor 2. Ikatan Ahli Arkeologi Indonesia, Jakarta.

Soenarto, Th. Aq, Imam Sunaryo, dan Dukut Santoso. 1987. Laporan Konservasi-Arkeologi Masjid Besar Kauman Yogyakarta. Suaka Peninggalan Sejarah dan Purbakala, Yogyakarta.

Subroto, Ph. 2003. Penjelasan yang disampaikan di Yogyakarta pada tanggal 18 September dan 2 Oktober 2003. 